\title{
Osteology and Myology of the Cephalic Region and Pectoral Girdle of Heptapterus mustelinus, Comparison With Other Heptapterins, and Discussion on the Synapomorphies and Phylogenetic Relationships of the Heptapterinae and the Pimelodidae (Teleostei: Siluriformes)
}

\author{
Osteología y Miología de la Región Cefálica y de la Cintura Pectoral del Heptapterus mustelinus, \\ Comparación con Otros Heptapterinos, y Discusión de las Sinapomorfías y Relaciones Filogenéticas \\ de los Heptapterinae y Pimelodidae (Telostei: Siluriformes)
}

${ }^{*, * *}$ Rui Diogo

DIOGO, R. Osteology and myology of the cephalic region and pectoral girdle of Heptapterus mustelinus, comparison with other heptapterins, and discussion on the synapomorphies and phylogenetic relationships of the Heptapterinae and the Pimelodidae (Teleostei: Siluriformes). Int. J. Morphol., 25(4):735-748, 2007.

SUMMARY: The cephalic and pectoral girdle structures of the heptapterin Hepapterus mustelinus ('Nemuroglanis clade') are described and compared to those of two representatives of the other, more plesiomorphic, main heptapterin group, namely Goeldiella eques and Rhamdia guatemalensis ('basal clade'), as well as of several other catfishes, as the foundation for a discussion on the synapomorphies and phylogenetic relationships of the Heptapterinae. In addition to the five synapomorphies commonly referred in the literature, there is another potential Heptapterinae synapomorphy: the well-developed maxilla forming a completely closed, deep tube to enclose the base of the maxillary barbel. The subfamilies Pimelodinae, Heptapterinae and Pseudopimeodinae seem to form a monophyletic assemblage, thus contradicting the commonly accepted idea that the family Pimelodidae is not a natural group.

KEY WORDS: Catfish; Heptapterinae; Morphology; Phylogeny; Pimelodidae; Siluriformes.

\section{INTRODUCTION}

The Siluriformes, with approximately 438 genera and over 2750 species, represent about $33 \%$ of all freshwater fishes and are one of the economically important groups of fresh and brackish water fishes in the world (Teugels, 2003). Among the 35 siluriform families (Ferraris \& De Pinna, 1999), the Pimelodidae, with more than 300 species, is one of the largest and most diverse Neotropical groups (De Pinna, 1998; Shibatta, 2003). In reality, most authors consider nowadays that such a diversity is due to the fact that the family Pimelodidae is a heterogeneous assemblage comprising "three major well-defined monophyletic groups, currently ranked as subfamilies, the Pimelodinae, Heptapterinae, and Pseudopimelodinae" that do not form a monophyletic "Pimelodidae" clade (De Pinna, 1998: 313).
Among these three subfamilies, the Heptapterinae, comprising 25 genera, forms "one of the largest radiations of Neotropical catfishes" (De Pinna, 1998: 315), being defined by five synapomorphies, namely a "posterior limb of fourth transverse process laterally expanded above swimbladder and notched once to several times", "neural spines of Weberian complex centrum joined by a straightedged, horizontal or sometimes sloping bony lamina", "process for insertion of levator operculi muscle on posterodorsal corner of hyomandibula greatly expanded", "quadrate with a free dorsal margin and bifid shape, its posterior and anterior limbs articulate separately with hyomandibula and metapterygoid" and "presence of an anteriorly recurved process drawn out from ventrolateral

\footnotetext{
Museo Nacional de Ciencias Naturales de Madrid, Spain.

** Laboratory of Functional and Evolutionary Morphology, University of Liège, Belgium.
} 
DIOGO, R. Osteology and myology of the cephalic region and pectoral girdle of Heptapterus mustelinus, comparison with other heptapterins, and discussion on the synapomorphies and phylogenetic relationships of the Heptapterinae and the Pimelodidae (Teleostei: Siluriformes). Int. J. Morphol., 25(4):735-748, 2007.

corner of mesethmoid" (Lundberg et al., 1991: 198-199). However, although the anatomy of the heptapterins have been the subject of some published studies (e.g. Chardon, 1968; Buckup, 1988; Ferraris, 1988; Lundberg \& McDade, 1986; Lundberg et al.; Arratia, 1992; Bockmann, 1994; Silfvergrip, 1996), most of these studies concerned mainly osteological structures of the cranium and/or pectoral girdle, and, therefore, some important aspects of the morphology of this vast group of catfishes are still practically unknown (e.g., their cranial muscles, the structures associated with their mandibular barbels, or the pectoral girdle musculature). This not only complicates the study of the functional morphology of the heptapterins, but also restricts considerably the data available to infer the synapomorphies and/or the phylogenetic relationships of these catfishes.

In this work I will describe the myological and osteological structures of both the cephalic region and the pectoral girdle of the heptapterin Heptapterus mustelinus (Valenciennes, 1836) ('Nemuroglanis clade'), and compare these structures with those of two representatives of the other main, more plesiomorphic, heptapterin group, namely Goeldiella eques (Müller \& Troschel, 1948) and Rhamdia guatemalensis (Günther, 1864) ('basal clade') (see Lundberg et al., 1991: 200-204), as well as of several other non-heptapterin catfishes, as the foundation for a discussion on the synapomorphies and phylogenetic relationships of the Heptapterinae. It is also hoped that this study could increase the knowledge of the anatomy and phylogeny of the catfishes in general, as well as pave the way for future works concerning the comparative anatomy, evolution, functional morphology, palaeontology, eco-morphology and particularly the phylogeny of these fishes.

\section{MATERIAL AND METHOD}

The fishes studied are from Laboratory of Functional and Evolutionary Morphology (LFEM), from the Musée Royal de l'Afrique Centrale of Tervuren (MRAC), from the Université Nationale du Bénin (UNB), from the Muséum National D'Histoire Naturelle of Paris (MNHN), from the National Museum of Natural History of Washington (USNM), and from the South African Institute for Aquatic Biodiversity (SAIAB) and the Albany Museum of Grahamstown (AMG). Anatomical descriptions are made after dissection of alcohol-fixed or trypsin-cleared and alizarine-stained (following Taylor \& Van Dyke's 1985 method) specimens. Dissections and morphological drawings were made using a Wild M5 dissecting microscope equipped with a camera lucida. The alcohol fixed (alc), trypsin-cleared and alizarine-stained (c\&s), or simply alizarine-stained (s) condition of the studied fishes is given in parentheses following the number of specimens dissected. A list of the specimens dissected is given below.

Akysidae: Akysis baramensis LFEM, 2 (alc). Akysis leucorhynchus USNM 109636, 2 (alc). Parakysis anomalopteryx USNM 230307, 2 (alc); LFEM, 1 (alc).

Amblycipitidae: Amblyceps caecutiens LFEM, 2 (alc). Amblyceps mangois USNM 109634, 2 (alc). Liobagrus reini USNM 089370, 2 (alc).

Amphiliidae: Amphilius brevis MRAC 89-043-P-403, 3 (alc); MRAC 89-043-P-2333, 1 (c\&s). Andersonia leptura MNHN 1961-0600, 2 (alc). Belonoglanis tenuis MRAC P.60494, 2 (alc). Doumea typica MRAC 93-041-P-1335, 1 (alc). Leptoglanis rotundiceps MRAC P.186591-93, 3 (alc). Paramphilius trichomycteroides LFEM, 2 (alc). Phractura brevicauda MRAC 90-057-P-5145, 2 (alc); MRAC 92-125-P-386, 1 (c\&s). Phractura intermedia MRAC 73-016-P-5888, 1 (alc). Trachyglanis ineac MRAC P.125552-125553, 2 (alc). Zaireichthys zonatus MRAC 89043-P-2243-2245, 3 (alc).

Ariidae: Arius hertzbergii LFEM, 1 (alc). Arius heudelotii LFEM, 4 (alc). Bagre marinus LFEM, 1 (alc); LFEM, 1 (c\&s). Genidens genidens LFEM, 2 (alc).

Aspredinidae: Aspredo aspredo USNM 226072, 1 (alc). Aspredo sicuephorus LFEM, 1 (alc). Bunocephalus knerii USNM 177206, 2 (alc). Xyliphius magdalenae USNM 120224, 1 (alc).

Astroblepidae: Astroblepus phelpis LFEM, 1 (alc); USNM 121127, 2 (alc).

Auchenipteridae: Ageneiosus vittatus USNM 257562, 1 (alc). Auchenipterus dentatus USNM 339222, 1 (alc). Centromochlus hechelii USNM 261397, 1 (alc).

Austroglanididae: Austroglanis gilli LFEM, 3 (alc); SAIAB 58416 (c\&s). Austroglanis sclateri AMG, 1 (c\&s); SAIAB 68917 (s).

Bagridae: Bagrichthys macropterus USNM 230275, 1 (alc). Bagrus bayad LFEM, 1 (alc); LFEM, 1 (c\&s). Bagrus docmak MRAC 86-07-P-512, 1 (alc); MRAC 86-07-P-516, 1 (c\&s). Hemibagrus nemurus USNM 317590, 1 (alc). Rita chrysea USNM 114948, 1 (alc).

Callichthyidae: Callichthys callichthys USNM 226210, 2 (alc). Corydoras guianensis LFEM, 2 (alc).

Cetopsidae: Cetopsis coecutiens USNM 265628, 2 (alc). Helogenes marmuratus USNM 264030, 1 (alc). Hemicetopsis candiru USNM 167854, 1 (alc).

Chacidae: Chaca bankanensis LFEM, 3 (alc). Chaca burmensis LFEM, 2 (alc). Chaca chaca LFEM, 2 (alc). 
DIOGO, R. Osteology and myology of the cephalic region and pectoral girdle of Heptapterus mustelinus, comparison with other heptapterins, and discussion on the synapomorphies and phylogenetic relationships of the Heptapterinae and the Pimelodidae (Teleostei: Siluriformes). Int. J. Morphol., 25(4):735-748, 2007.

Clariidae: Clarias anguillaris LFEM, 2 (alc). Clarias batrachus LFEM, 2 (alc). Clarias ebriensis LFEM, 2 (alc). Clarias gariepinus MRAC 93-152-P-1356, 1 (alc), LFEM, 2 (alc). Heterobranchus bidorsalis LFEM, 2 (alc). Heterobranchus longifilis LFEM, 2 (alc). Uegitglanis zammaronoi MRAC P-15361, 1 (alc).

Claroteidae: Auchenoglanis biscutatus MRAC 73-015-P999, 2 (alc). Auchenoglanis occidentalis LFEM, 2 (alc). Chrysichthys auratus UNB, 2 (alc); UNB, 2 (c\&s). Chrysichthys nigrodigitatus UNB, 2 (alc); UNB, 2 (c\&s). Clarotes laticeps MRAC 73-13-P-980, 2 (alc).

Cranoglanididae: Cranoglanis bouderius LFEM, 2 (alc).

Diplomystidae: Diplomystes chilensis LFEM, 3 (alc).

Doradidae: Acanthodoras cataphractus USNM 034433, 2 (alc). Anadoras weddellii USNM 317965, 2 (alc). Doras brevis LFEM, 2 (alc). Doras punctatus USNM 284575, 2 (alc). Franciscodoras marmoratus USNM 196712, 2 (alc).

Erethistidae: Erethistes pusillus USNM 044759, 2 (alc). Hara filamentosa USNM 288437, 1 (alc).

Heteropneustidae: Heteropneustes fossilis USNM 343564 , 2 (alc); USNM 274063, 1 (alc); LFEM, 2 (alc).

Ictaluridae: Amiurus nebolosus USNM 246143, 1 (alc); USNM 73712, 1 (alc). Ictalurus furcatus LFEM, 2 (alc). Ictalurus punctatus USNM 244950, 2 (alc).

Loricariidae: Hypoptopoma bilobatum LFEM, 2 (alc). Hypoptopoma inexspectata LFEM, 2 (alc). Lithoxus lithoides LFEM, 2 (alc). Loricaria cataphracta LFEM, 1 (alc). Loricaria loricaria USNM 305366, 2 (alc); USNM 314311, 1 (alc).

Malapteruridae: Malapterurus electricus LFEM, 5 (alc).

Mochokidae: Mochokus niloticus MRAC P.119413, 1 (alc); MRAC P.119415, 1 (alc). Synodontis clarias USNM 229790, 1 (alc). Synodontis schall LFEM, 2 (alc). Synodontis sorex LFEM, 2 (alc).

Nematogenyidae: Nematogenys inermis USNM 084346, 2 (alc); LFEM, 2 (alc).

Pangasiidae: Helicophagus leptorhynchus USNM 355238 , 1 (alc). Pangasius larnaudii USNM 288673, 1 (alc). Pangasius sianensis USNM 316837, 2 (alc).

Pimelodidae: Batrochoglanis raninus USNM 226136, 3 (alc). Calophysus macropterus USNM 306962, 1 (alc); LFEM, 1 (alc). Goeldiella eques USNM 066180, 3 (alc). Hepapterus mustelinus USNM 287058, 2 (alc) ; LFEM, 2 (alc). Hypophthalmus edentatus USNM 226140, 1 (alc); LFEM, 1 (alc). Microglanis cottoides USNM 285838, 2 (alc). Pimelodus blochii LFEM, 2 (alc). Pseudoplatystoma fasciatum USNM 284814, 2 (alc). Rhamdia guatemalensis USNM 114494, 2 (alc); LFEM, 1 (alc).
Plotosidae: Cnidoglanis macrocephalus USNM 219580, 2 (alc). Neosilurus rendahli USNM 173554, 2 (alc). Paraplotosus albilabris USNM 173554, 2 (alc). Plotosus anguillaris LFEM, 2(alc). Plotosus lineatus USNM 200226), 2 (alc).

Schilbidae: Ailia colia USNM 165080, 1 (alc). Laides hexanema USNM 316734, 1 (alc). Pseudeutropius brachypopterus USNM 230301, 1 (alc). Schilbe intermedius MRAC P.58661, 1 (alc). Schilbe mystus LFEM, 3 (alc). Siluranodon auritus USNM 061302, 2 (alc).

Scoloplacidae: Scoloplax distolothrix LFEM, 1 (alc); USNM 232408, 1 (alc).

Siluridae: Silurus aristotelis LFEM, 2( alc). Silurus glanis LFEM, 2 (alc). Silurus asotus USNM 130504, 2 (alc). Wallago attu USNM 304884, 1 (alc).

Sisoridae: Bagarius yarreli USNM 348830, 2 (alc); LFEM, 1 (c\&s). Gagata cenia USNM 109610, 2 (alc). Glyptosternon reticulatum USNM 165114, 1 (alc). Glyptothorax fukiensis USNM 087613, 2 (alc).

Trichomycteridae: Hatcheria macraei LFEM, 2 (alc). Trichomycterus areolatus LFEM, 2 (alc). Trichomycterus banneaui LFEM, 2 (alc). Trichomycterus immaculatus USNM 301015, 2 (alc).

\section{RESULTS}

In this section, I will describe in detail the myological and osteological structures of both the cephalic region and the pectoral girdle of the heptapterin Heptapterus mustelinus ('Nemuroglanis clade'), and compare these structures with those of two representatives of the other main, more plesiomorphic, heptapterin group, Goeldiella eques and Rhamdia guatemalensis ('basal clade'). In the anatomical descriptions, the nomenclature for the osteological structures of the cephalic region follows basically that of Diogo (2004). The myological nomenclature is based mainly on Winterbottom (1974), but for the different adductor mandibulae sections, for reasons explained in Gosline (1989) and Diogo \& Chardon (2000a), I follow Diogo \& Chardon (2000a). In relation to the muscles associated with the mandibular barbels, Diogo \& Chardon (2000b) is followed. Concerning the nomenclature of the pectoral girdle bones and muscles, Diogo et al. (2001b) is followed.

\section{Heptapterus mustelinus}

\section{Osteology}

Os mesethmoideum. Situated on the antero-dorsal surface of the neurocranium (Fig. 1), with each of its antero- 
DIOGO, R. Osteology and myology of the cephalic region and pectoral girdle of Heptapterus mustelinus, comparison with other heptapterins, and discussion on the synapomorphies and phylogenetic relationships of the Heptapterinae and the Pimelodidae (Teleostei: Siluriformes). Int. J. Morphol., 25(4):735-748, 2007.

ventro-lateral margins ligamentously connected to the premaxilla. The mesethmoid presents a prominent, anteriorly recurved process ("mesethmoid hook" sensu Lundberg \& McDade) drawn out from its ventrolateral surface.

Os lateroethmoideum. The lateral ethmoid is an irregular, large bone (Fig. 1). The ethmoid cartilage, situated ventrally to both the lateral ethmoid and the mesethmoid, is well-developed, with its anterior portion being markedly extended anteriorly and almost reaching the posterior surface of the premaxillaries.

Os praevomerale. T-shaped bone with developed anterolateral arms and without ventral tooth-plates.

Os orbitosphenoideum. Posterior to the lateral ethmoid (Fig. 1), with the dorsal edge of its lateral wall being sutured with the ventral surface of the frontal.

Os pterosphenoideum. Posterior to the orbitosphenoid (Fig. 1), covering, together with this bone, the gap between the frontals and the parasphenoid.

Os parasphenoideum. The parasphenoid is the longest bone of the cranium. It bears a pair of ascending flanges, which suture with the pterosphenoids and prootics.

Os frontale. The frontals (Fig. 1) are large bones that constitute a great part of the cranial roof. They are largely separated by two well-developed fontanels.

Os sphenoticum. This bone (Fig. 1) constitutes, together with the pterotic, a well-developed, deep articulatory facet for the hyomandibulo-metapterygoid.

Os pteroticum. Well-developed, irregularly-shaped bone situated posteriorly to the sphenotic (Fig. 1).

Os prooticum. Together with the pterosphenoid and the parasphenoid, it borders the well-developed foramen of the trigemino-facial nerve complex.

Os epioccipitale. Situated on the posterior surface of the neurocranium.

Os exoccipitale. The well-developed exoccipitals are situated laterally to the basioccipital.

Os extrascapulare. Small bone (Fig. 1) situated on the postero-dorso-lateral surface of the neurocranium, between the posttemporo-supracleithrum, the pterotic and the parieto-supraoccipital.
Os basioccipitale. Well-developed, unpaired bone, forming the posteriormost part of the floor of the neurocranium. Its ventro-lateral surfaces are ligamentously connected to the ventro-medial limbs of the posttemporo-supracleithra.

Os parieto-supraoccipitale. Large bone (Fig. 1) constituting the postero-dorso-median surface of the cranial roof. It bears a small, short, posteriorly pointed, triangular postero-median process.

Os angulo-articulare. This bone (Fig. 1), together with the dentary bone, coronomeckelian and Meckel's cartilage, constitute the mandible. Postero-ventrally, the angulo-articular is ligamentously connected to both the interopercle and the posterior ceratohyal. Postero-dorsally, it presents an articulatory facet for the quadrate-symplectic.

Os dentale. The postero-dorsal margin of the toothed (Fig. 1) dentary forms, together with the antero-dorsal margin of the angulo-articular, a well-developed dorsal process (processus coronoideus).

Os coronomeckelium. Well-developed, it is lodged in the medial surface of the mandible. Posterodorsally it bears a crest for attachment of the adductor mandibulae A3'-d.

Os praemaxillare. Well-developed bone presenting a prominent dorsolateral process (Fig. 1: o-prmx-dlp) for the attachment of a short, but strong, ligament connecting this bone to the premaxilla. Ventrally, the premaxilla bears a well-developed tooth-plate with numerous small teeth having their tips slightly turned backward (Fig. 1).

Os maxillare. The maxilla is a well-developed bone forming a completely enclosed, deep tube (Fig. 1) to receive the base of the maxillary barbel and being connected by means of a short but strong ligament to the premaxilla.

Os autopalatinum. The autopalatine (Fig. 1) is a rodlike, anteroposteriorly elongated bone with its posterior portion slightly expanded dorsoventrally. Its posterior end is capped by a small cartilage and its anterior end is tipped by a somewhat well-developed cartilage with two anterolateral concavities, which accept the two proximal heads of the maxilla. Medially, the autopalatine articulates, by means of an elongated articulatory surface, with the lateral ethmoid.

Os hyomandibulo-metapterygoideum. The homology, and, thus, the correct denomination, of this bone, as well as of the other suspensorium elements of catfish, has been the subject of endless controversies (e.g. McMurrich, 1884; Gosline, 1975; Howes, 1983, 1985; Arratia; Diogo et al., 2001a; Diogo \& Chardon, 2003). As referred before, for the 
DIOGO, R. Osteology and myology of the cephalic region and pectoral girdle of Heptapterus mustelinus, comparison with other heptapterins, and discussion on the synapomorphies and phylogenetic relationships of the Heptapterinae and the Pimelodidae (Teleostei: Siluriformes). Int. J. Morphol., 25(4):735-748, 2007.

several reasons explained in detail in our recent papers (Diogo et al., 2001a; Diogo \& Chardon, 2003), the nomenclature used here to describe these elements will follows that presented by Diogo et al. (2001a). The hyomandibulometapterygoid (Fig. 1) is a large bone presenting a prominent posterodorsal process for the insertion of the muscle levator operculi and articulating dorsally with both the pterotic and the sphenotic and posteriorly with the opercle.

Os sesamoideum 1. Well-developed, somewhat triangular bone attached, by means of two thick ligaments, to the ento-ectopterygoid posteriorly and to vomer anteriorly. The sesamoid bones 2 and 3 (see Diogo et al., 2001a) are absent.

Os entopterygoide-ectopterygoideum. Welldeveloped, irregular bone posteriorly sutured with the quadrate-symplectic and completely separated from the hyomandibulo-metapterygoid by this latter bone. Anteriorly, it is connected, by means of a short but strong ligament to the sesamoid bone 1 of the suspensorium.

Os quadrato-symplecticum. The quadratesymplectic (Fig. 1) presents a well-developed anterior articulatory surface to articulate with the postero-dorsal surface of the angulo-articular. It presents a deep, somewhat circular concavity on its antero-ventro-mesial surface.

Os praeoperculare. Long and thin bone (Fig.1) firmly sutured to both the hyomandibulo-metapterygoid and the quadrate-symplectic.

Os operculare. The opercle (Fig.1) is a large, roughly triangular bone attached ventrally, by means of connective tissue, to the interopercle. It presents a well-developed antero-dorsal articulatory surface for the hyomandibulometapterygoid.

Os interoperculare. Its anterior surface is ligamentously connected to the postero-ventral margin of the mandible (Fig. 1). Medially, the interopercle is attached, by means of massive connective tissue, to the lateral surface of the posterior ceratohyal.

Os interhyale. Small-bone ligamentously connected to the hyomandibulo-metapterygoid, dorsally, and to the posterior ceratohyal, ventrally.

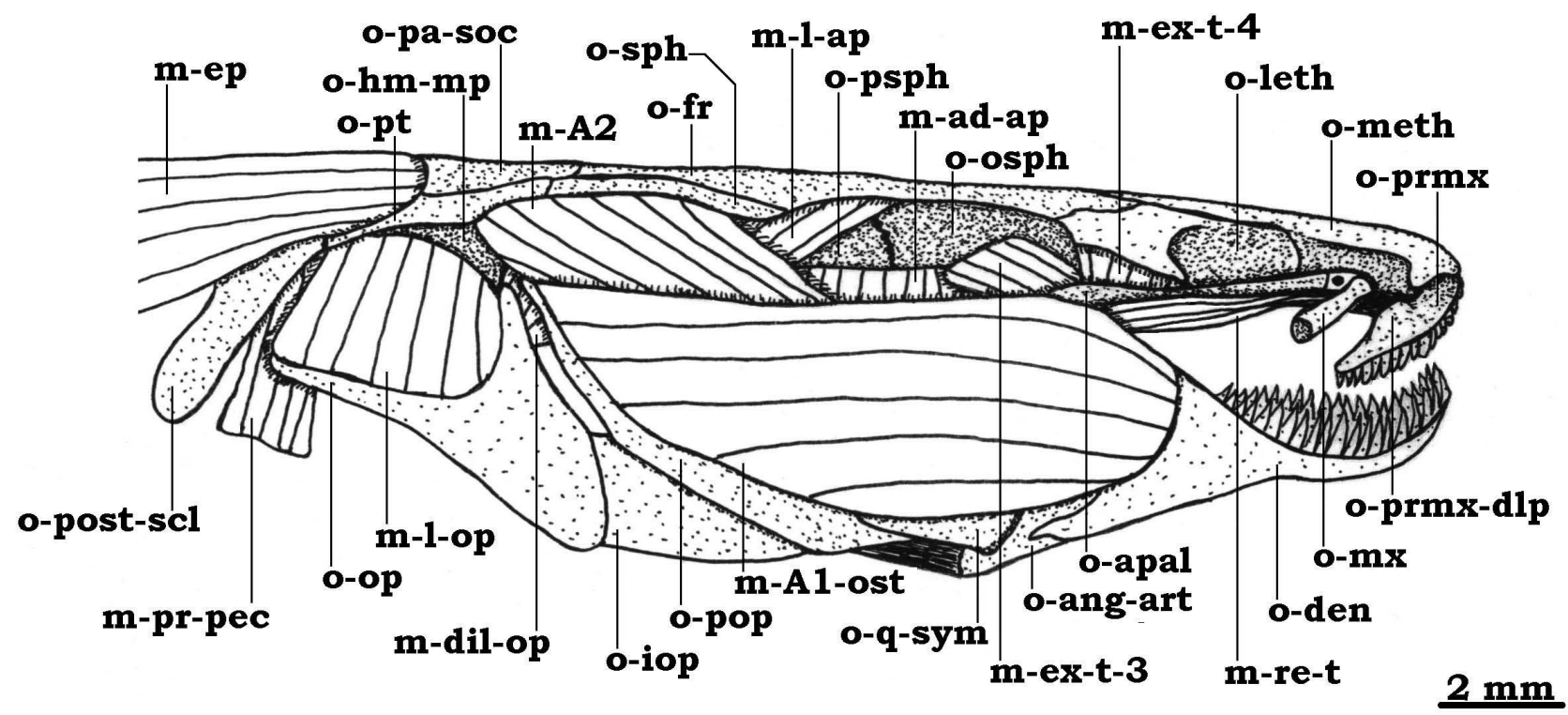

Fig. 1. Lateral view of the cephalic musculature of Heptapterus mustelinus. All the muscles are exposed. $m$-Al-ost, $m$-A2, $m$ - $A 3$ '- $d$ sections of musculus adductor mandibulae, $m$-ad-ap musculus adductor arcus palatini, $m$-dil-op musculus dilatator operculi, $m$-ep musculus epaxialis, $m-e x-t-3, m-e x-t-4$ sections of musculus extensor tentaculi, $m$ - $l$-ap musculus levator arcus palatini, $m$ - $l$-op musculus levator operculi, $m$-pr-pec musculus protractor pectoralis, $m$-re- $t$ musculus retractor tentaculi, $o$-ang-art os angulo-articulare, o-apal os autopalatinum, o-den os dentale, o-fr os frontale, o-hm-mp os hyomandibulometapterygoideum, $o$-iop os interoperculare, $o$-leth os latero-ethmoideum, $o$-meth os mesethmoideum, $o$ - $m x$ os maxillare, $o$-op os operculare, $o$-osph os orbitosphenoideum, o-pa-soc os parieto-supraoccipitale, o-pop os praeoperculare, $o$ - $p o s t$-scl os posttemporo-supracleithrum, o-prmx os praemaxillare, o-prmx-dlp dorsolateral process of os praemaxillare, $o$-psph os pterosphenoideum, $o$ - $p t$ os pteroticum, $o$ - $q$-sym os quadrato-symplecticum, $o$-sph os sphenoticum. 
DIOGO, R. Osteology and myology of the cephalic region and pectoral girdle of Heptapterus mustelinus, comparison with other heptapterins, and discussion on the synapomorphies and phylogenetic relationships of the Heptapterinae and the Pimelodidae (Teleostei: Siluriformes). Int. J. Morphol., 25(4):735-748, 2007.

Os ceratohyale posterior. Well-developed, somewhat triangular bone connected, by means of two strong ligaments, to the postero-ventral edge of the mandible and to the interhyal, respectively.

Os ceratohyale anterior. Elongated, stout bone that supports, together with the posterior ceratohyal, the branchiostegal rays.

Os hypohyale ventrale. The ventral hypohyals are ligamentously connected to the antero-lateral edges of the parurohyal.

Os hypohyale dorsale. These are small bones situated dorsally to the ventral hypohyals.

Os parurohyale. The parurohyal is a large, irregular bone lying medially behind the symphysis of the two ventral hypohyals and presenting a small, posteriorly pointed triangular posteromedial process.

Os posttemporo-supracleithrum. This bone (Fig. 1), together with the cleithrum and the scapulo-coracoid, constitute the pectoral girdle. Its dorso-medial limb is loosely attached to the neurocranium and its ventromedial limb is ligamentously connected to the basioccipital. Its postero-lateral margin is deeply forked, forming an articulating groove for the upper edge of the cleithrum.

Os cleithrum. The cleithrum (Fig. 2) is a large, well-ossified stout structure presenting a prominent antero-dorsal projection of laminar bone (Fig. 2: o-cladp) and forming a great part of the pectoral girdle and the posterior boundary of the branchial chamber. It contacts its counterpart in the antero-medial line via connective tissue and bears a deep crescentic, medially faced groove that accommodates the dorsal condyle of the pectoral spine. The humeral process of the cleithrum is undifferentiated.

Os scapulo-coracoideum. This is an elongated, irregular bony plate (Fig. 2) suturing with the cleithrum along its antero-lateral edge. Antero-laterally, it presents a anteriorly directed process, usually called the coracoid bridge (see Diogo et al., 2001b), which extends ventrally to the ventro-lateral surface of the cleithrum, fusing with an antero-ventral ridge of this bone. Mesially, the scapulo-coracoid joins its counterpart in an interdigitation of several strong serrations. Postero-laterally, it bears two condyles, which articulate, respectively, with the pectoral spine and the complex radial (see Mo, 1991). There is a well-developed mesocoracoid arch.
Myology

Musculus adductor mandibulae. The adductor mandibulae A1-ost (see Diogo \& Chardon 2000a) originates on the preopercle, hyomandibulo-metapterygoid and quadrate-symplectic and inserts on the posterodorsal surface of the angulo-articular (Fig. 1). The A2 (Fig. 1), which lies dorso-mesially to the A1-ost, runs from sphenotic, the pterotic, the preopercle and the hyomandibulo-metapterygoid to the medial surface of the dentary bone. The adductor mandibulae A 3 ' is divided into a dorsal and a ventral part. The dorsal one (A3'-d), originates on both the hyomandibulo-metapterygoid and the quadrate-symplectic and inserts tendinously on the coronomeckelian bone, while the ventral one (A3'-v) originates on the quadrate-symplectic and the hyomandibulo-metapterygoid and inserts on the medial surface of the angulo-articular. The adductor mandibulae A3", situated mesially to the A3', runs from the hyomandibulo-metapterygoid to the well-developed coronomeckelian bone. Lastly, the adductor mandibulae Aw, which is well-developed, attaches anteriorly on the mesial surface of both the dentary and the angulo-articular and posteriorly on the tendon of the A2.

Musculus levator arcus palatini. The levator arcus palatini (Fig. 1) is situated medially to the adductor mandibulae $\mathrm{A} 3$ '. It originates on the sphenotic, frontal and pterosphenoid and inserts on the lateral face of the hyomandibulo-metapterygoid.

Musculus adductor arcus palatini. This muscle (Fig. 1) runs from the parasphenoid, pterosphenoid and orbitosphenoid to the hyomandibulo-metapterygoid, the quadrate-symplectic and the ento-ectopterygoid.

Musculus levator operculi. It originates on both the ventro-lateral margin of the pterotic and the postero-dorso-lateral surface of the hyomandibulo-metapterygoid and inserts on both the dorsal and the latero-dorsal surfaces of the opercle (Fig. 1).

Musculus adductor operculi. Situated medially to the levator operculi, it originates on the ventral surface of the pterotic and inserts on the dorso-medial surface of the opercle.

Musculus adductor hyomandibularis. Small muscle situated mesially to the levator operculi but laterally to the adductor operculi. It originates on the ventral surface of the pterotic and inserts on the postero-dorso-median surface of the hyomandibulo-metapterygoid. 
DIOGO, R. Osteology and myology of the cephalic region and pectoral girdle of Heptapterus mustelinus, comparison with other heptapterins, and discussion on the synapomorphies and phylogenetic relationships of the Heptapterinae and the Pimelodidae (Teleostei: Siluriformes). Int. J. Morphol., 25(4):735-748, 2007.

Musculus dilatator operculi. The dilatator operculi (Fig. 1) originates on the pterosphenoid, frontal and sphenotic and inserts on the antero-dorsal margin of the opercle.

Musculus extensor tentaculi. This muscle is divided into four bundles. The extensor tentaculi 1 runs from the lateral ethmoid to both the postero-ventral and the posteromesial surfaces of the autopalatine. The extensor tentaculi 2 (Fig. 1) originates on the lateral ethmoid and inserts on the postero-dorsal surface of the autopalatine. The extensor tentaculi 3 (Fig. 1) runs from the lateral ethmoid and the orbitosphenoid to the postero-ventral margin of the autopalatine. Lastly, the extensor tentaculi 4 (Fig. 1) originates on both the orbitosphenoid and the lateral ethmoid and inserts on the postero-dorsal surface of the autopalatine.

Musculus retractor tentaculi. Well-developed muscle (Fig. 1) originating on both the quadrate-symplectic and the ento-ectopterygoid and inserting tendinously on the posterior surface of the maxillary bone.

Musculus protractor hyoidei. This muscle (Fig. 3) has 3 parts. The pars ventralis, in which are lodged both the cartilages associated with the internal and external

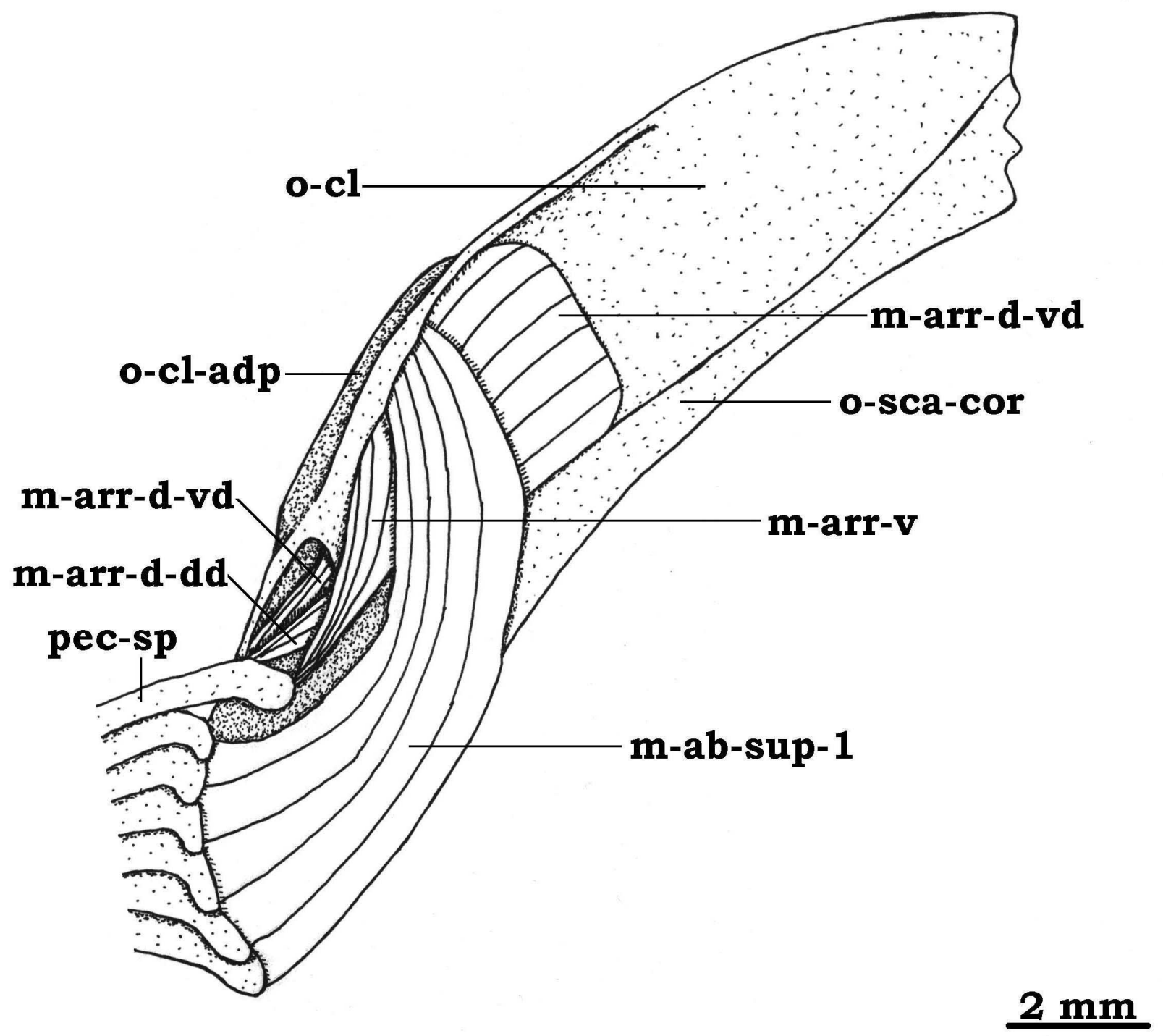

Fig. 2. Ventral view of the pectoral girdle musculature of Heptapterus mustelinus. All the muscles are exposed. m-ab-sup1 section of musculus abductor superficialis, $m$-arr- $d$ - $d d, m$-arr- $d$ - $v d$ dorsal and ventral divisions of musculus arrector dorsalis, $m$-arr- $v$, musculus arrector ventralis, $o$ - $c l$ os cleithrum, $o$ - $c l$-adp anterodorsal projection of os cleithrum, $o$-sca-cor os scapulo-coracoide, $p e c$-sp pectoral spine. 
DIOGO, R. Osteology and myology of the cephalic region and pectoral girdle of Heptapterus mustelinus, comparison with other heptapterins, and discussion on the synapomorphies and phylogenetic relationships of the Heptapterinae and the Pimelodidae (Teleostei: Siluriformes). Int. J. Morphol., 25(4):735-748, 2007.

mandibular barbels (Fig. 3: c-in-mnd-t; c-ex-mnd-t) and the large cartilaginous plate carrying these barbels (Fig. 3: cpmnd-b) (see Ghiot, 1978; Diogo \& Chardon, 2000b), originates on the anterior ceratohyal and inserts on the dentary bone, meeting its counterpart in a well-developed median aponeurosis (Fig. 3). The pars lateralis runs from the posterior ceratohyal to the ventro-medial face of the dentary bone (Fig. 3). The pars dorsalis runs from the ante- rior and posterior ceratohyals to the antero-dorsal surface of the dentary bone.

Musculus retractor externi mandibularis tentaculi. Small muscles (Fig. 4) situated dorsally to the cartilaginous plates carrying the mandibular barbels. They run from the antero-dorsal surface of the moving part (see Diogo and Chardon 2000b) of the cartilages associated with the outer

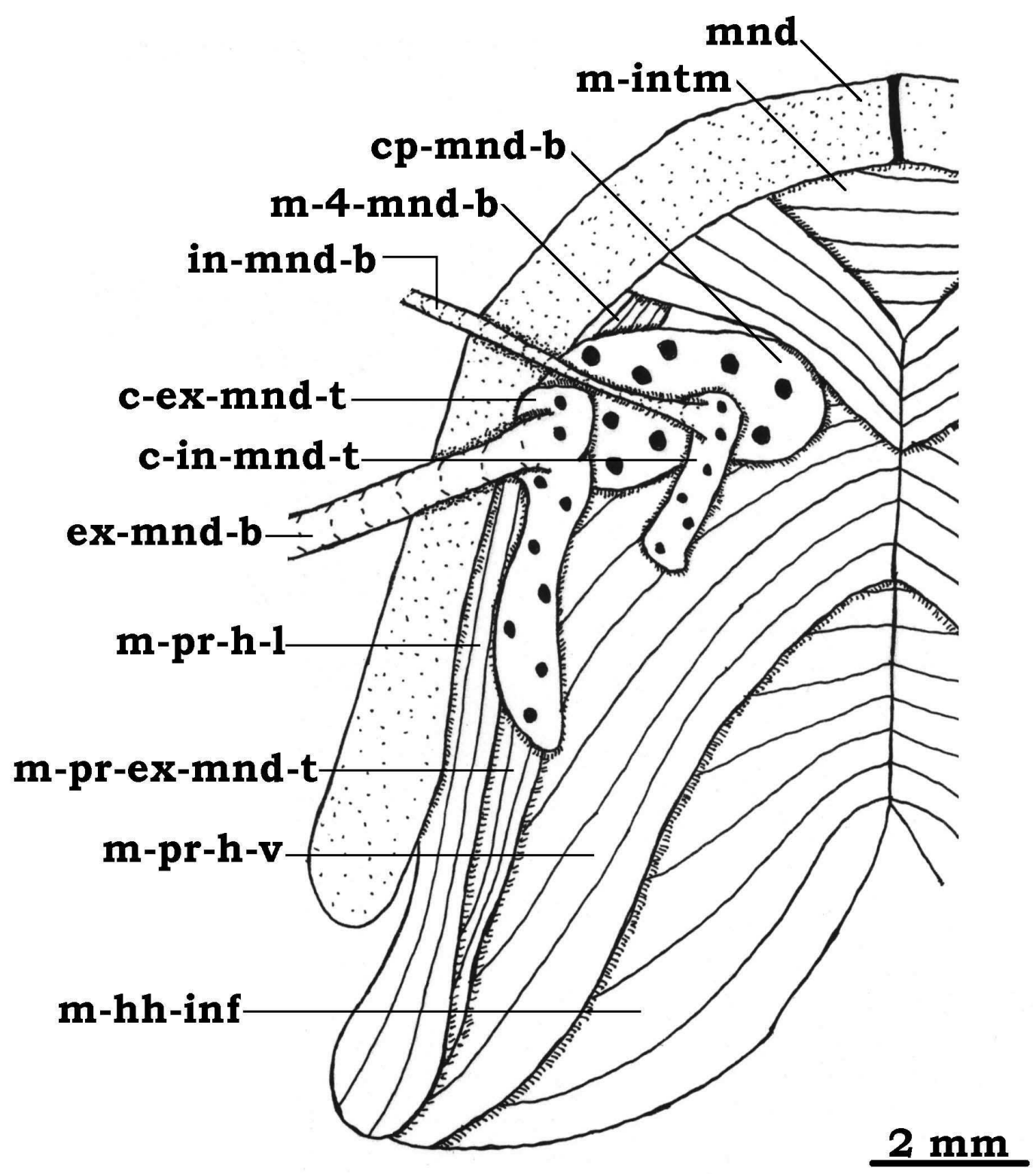

Fig. 3. Ventral view of the cephalic musculature of Heptapterus mustelinus. All the muscles are exposed.c-in-mnd- $t$ cartilago internus mandibularis tentaculi, $c$-ex-mnd- $t$ cartilago externus mandibularis tentaculi, $c p-m n d-b$ cartilaginous plate carrying the mandibular barbels, ex-mnd-b, in-mnd-b external and internal mandibular barbels, $m$ - 4 - $m n d-b$ muscle 4 of the mandibular barbels, $m$-hh-inf musculus hyohyoideus inferior, $m$-intm musculus intermandibularis, $m n d$ mandible, $m$ - $p r$-ex-mnd-t musculus protractor externi mandibularis tentaculi, $m-p r-h-l, m-p r-h-v$ pars lateralis and ventralis of musculus protactor hyoideus. 
DIOGO, R. Osteology and myology of the cephalic region and pectoral girdle of Heptapterus mustelinus, comparison with other heptapterins, and discussion on the synapomorphies and phylogenetic relationships of the Heptapterinae and the Pimelodidae (Teleostei: Siluriformes). Int. J. Morphol., 25(4):735-748, 2007.

mandibular barbels to the postero-dorsal surface of these cartilaginous plates.

Musculus retractor interni mandibularis tentaculi. These small muscles are also situated dorsally to the large cartilaginous plates carrying the mandibular barbels (Fig. 4). They run from both the dorso-medial surface of these plates and the antero-dorsal surface of the dentaries to the antero-dorsal surface of the moving part of the cartilages associated with the internal mandibular barbels.

Musculus protractor externi mandibularis tentaculi. Well-developed, elongated muscles (Figs 3, 4) originating on the posterior ceratohyals and inserting on the anterodorsal surface of the moving part of the cartilages associated with the outer mandibular barbels. It is important to register, in addition to the protractor and the two retractor muscles of the mandibular barbels described above, which are present in a large number of catfishes (Diogo \& Chardon, $2000 \mathrm{~b}$ ), the presence of a small, paired muscle associated with these barbels. This is the 'muscle 4 of the mandibular barbels' (Fig. 4: m-4-mnd-b), which attaches anteriorly on both the dorsal surface of the cartilaginous plate carrying the mandibular barbels and the dentary bone, and attaches posteriorly to the antero-dorsal margin of the cartilage associated with the external mandibular barbel (with respect to the nomenclature of this muscle, see Diogo \& Chardon 2000b).

Muscle intermandibularis. Well-developed muscle joining the two mandibles (Fig. 3).

Musculus hyohyoideus inferior. Thick muscle (Fig. 3) attaching medially on a median aponeurosis and laterally on the ventral surfaces of the ventral hypohyal, the anterior ceratohyal and the posterior ceratohyal.

Musculus hyohyoideus abductor. It runs from the first (medial) branchiostegal ray to a median aponeurosis, which is associated with two long, strong tendons, attached, respectively, to the two ventral hypohyals.

Musculus hyohyoideus adductor. Each hyohyoideus adductor connects the branchiostegal rays of the respective side.

Musculus sternohyoideus. It runs from the posterior portion of the parurohyal to the anterior portion of the cleithrum.

Musculus arrector ventralis. It runs from both the cleithrum and the scapulo-coracoid to the ventral condyle of the pectoral spine (Fig. 2).
Musculus arrector dorsalis. This muscle, dorsal to the arrector ventralis and the abductor superficialis, is differentiated into two well-developed divisions. The ventral division (Fig. 2: m-arr-d-vd), situated on the ventral surface of the pectoral girdle, originates on the ventral margin of the cleithrum and inserts on the antero-lateral edge of the pectoral spine. The dorsal division (Fig. 2: m-arr-d-dd), situated on the dorsal surface of the pectoral girdle, originates on the dorso-medial edge of the scapulo-coracoid and inserts on the anterior edge of the dorsal condyle of the pectoral spine.

Musculus abductor profundus. This well-developed muscle originates on the posterior surface of the scapulocoracoid and inserts on the medial surface of the dorsal condyle of the pectoral spine.

Musculus abductor superficialis. This muscle is differentiated into two sections. The larger section (Fig. 2: mab-sup-1) runs from the ventral margins of both the cleithrum and the scapulo-coracoid to the antero-ventral margin of the ventral part of the pectoral fin rays. The smaller section, situated dorsally to the larger one, runs from the lateral edge of the scapulo-coracoid to the antero-dorsal margin of the ventral part of the pectoral fin rays.

Musculus adductor superficialis. This muscle situates on the posterior margin of the pectoral girdle and is divided into two sections. The larger section originates on the posterior surfaces of both the cleithrum and the scapulo-coracoid and inserts on the antero-dorsal margin of the dorsal part of the pectoral fin rays. The smaller section runs from both the postero-ventro-lateral edge of the scapulo-coracoid and the dorsal surface of the proximal radials to the antero-ventral margin of the dorsal part of the pectoral fin rays.

Musculus protractor pectoralis. Well-developed muscle (Fig. 1) running from the ventral surfaces of both the pterotic and the posttemporo-supracleithrum to the anterodorsal surface of the cleithrum.

\section{Goeldiella eques}

The principal differences between the structures of the cephalic region and pectoral girdle of $H$. mustelinus and those of G. eques are that in this latter species: 1) the humeral process of the cleithrum is well-developed; 2) the muscle abductor profundus is significantly more developed than that of $H$. mustelinus; 3) the pectoral spine is considerably thicker than that of H.mustelinus and, contrary to that of this latter species, bears numerous, strong, dentations on both its inner and its outer surfaces; 4) the posterior surface of the scapulo-coracoid is pierced by a small, circular foramen in which lodges the anterior condyle of the pectoral spine when this latter is 
DIOGO, R. Osteology and myology of the cephalic region and pectoral girdle of Heptapterus mustelinus, comparison with other heptapterins, and discussion on the synapomorphies and phylogenetic relationships of the Heptapterinae and the Pimelodidae (Teleostei: Siluriformes). Int. J. Morphol., 25(4):735-748, 2007.

abducted; 5) the dorsal condyle of the pectoral spine presents a well-developed, triangular anterior process; 6) the anterodorsal lamina of the cleithrum is more developed than that of H. mustelinus; 7) the levator operculi inserts only on the dorsal surface, and not on both the dorsal and the dorso-lateral surfaces, of the opercle; 8) the antero-ventral surface of the quadrate-symplectic is completely pierced by a small, circular foramen; 9) the adductor mandibulae A2 does not contact the neurocranium, originating exclusively on the suspensorium; 10) the adductor mandibulae A3" is missing; 11) there is a well-developed dorsal concavity on the cranial roof between the dorsal surfaces of the lateral ethmoid and the frontal; 12) the posterior process of the parieto-supraoccipital is considerably more developed than that of $H$. mustelinus, forming a large, triangular structure.

\section{Rhamdia guatemalensis}

The principal differences between the structures of the pectoral girdle and cephalic region of $R$. guatemalensis and those of H. mustelinus are that in the former species: 1) the humeral process of the cleithrum is well-developed; 2) the scapulo-coracoid presents a prominent postero-lateral spine pointed posteriorly; 3 ) the muscle abductor profundus is significantly more developed than that of H.mustelinus; 4) there is only one fontanel on the dorsomedial surface of the cranial roof; 5) the pectoral spine is considerably thicker than that of $H$. mustelinus and, contrary to that of this latter species, bears numerous, strong, dentations on both its inner and its outer surfaces; 6) the ento-ectopterygoid is markedly bifurcated anteriorly; 7) the posterior surface of the scapulocoracoid is pierced by a small, circular foramen in which lodges the anterior condyle of the pectoral spine when this latter is abducted; 8) the dorsal condyle of the pectoral spine presents a well-developed, triangular anterior process; 9) the posterior process of the parieto-supraoccipital is considerably more developed than that of H. mustelinus, forming a large, triangular structure; 10) the antero-dorsal lamina of the cleithrum is more developed than that of $H$. mustelinus; 11) the levator operculi inserts only on the dorsal surface, and not on both the dorsal and the dorso-lateral surfaces, of the opercular bone; 12) the antero-ventral surface of the quadrate-symplectic is completely pierced by a small, circular foramen.

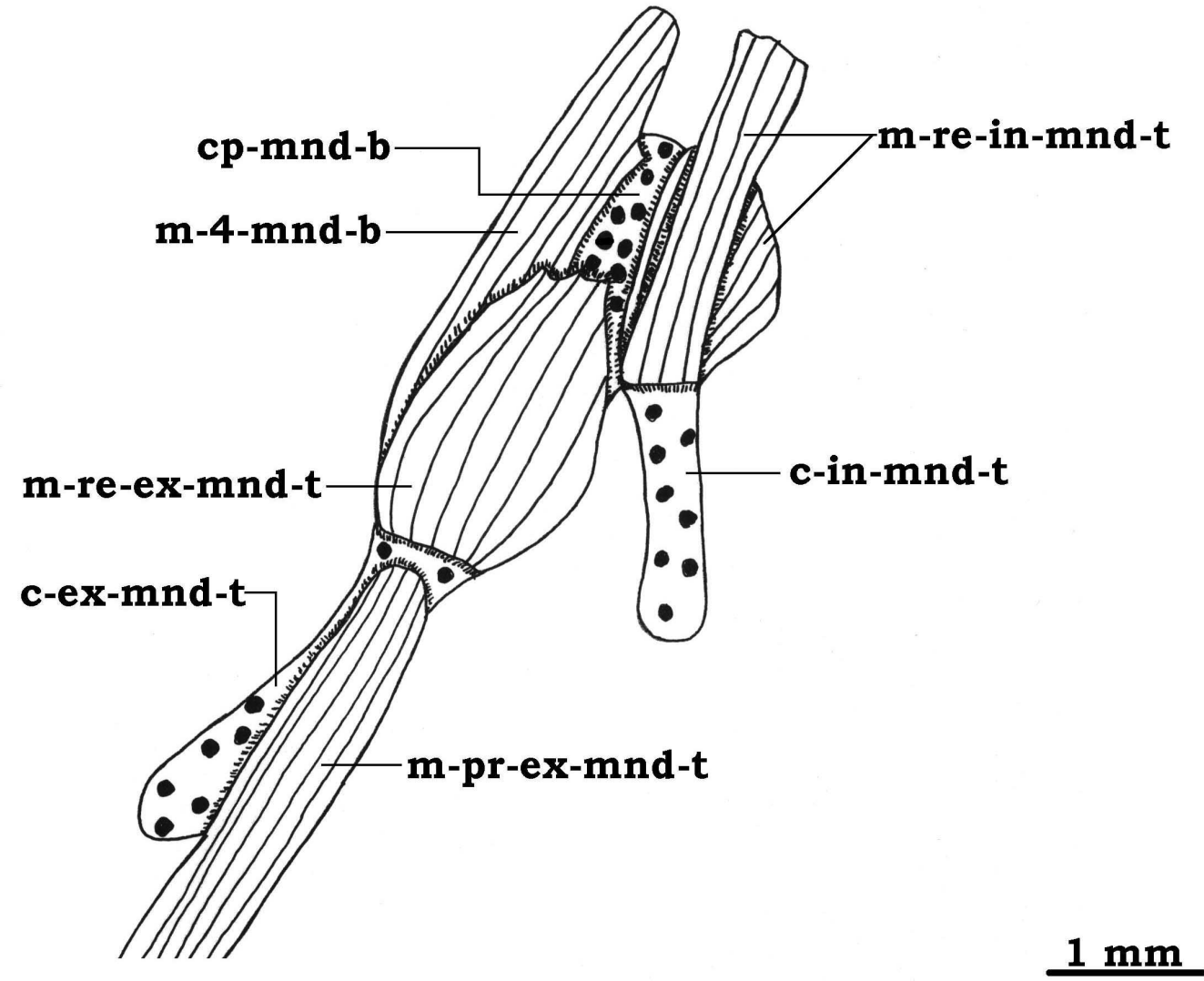

Fig. 4. Dorsal view of the left cartilaginous plate carrying the mandibular barbels and its associated structures in Heptapterus mustelinus. $c$-in-mnd- $t$ cartilago internus mandibularis tentaculi, $c$-ex-mnd- $t$ cartilago externus mandibularis tentaculi, $c p$-mnd- $b$ cartilaginous plate carrying the mandibular barbels, $m-4-m n d-b$ 'muscle 4 of the mandibular barbels', m-pr-ex-mnd-t musculus protractor externi mandibularis tentaculi, $m$-re-ex$m n d-t$ musculus retractor externi mandibularis tentaculi, $m$-re-in-mnd- $t$ musculus retractor interni mandibularis tentaculi. 
DIOGO, R. Osteology and myology of the cephalic region and pectoral girdle of Heptapterus mustelinus, comparison with other heptapterins, and discussion on the synapomorphies and phylogenetic relationships of the Heptapterinae and the Pimelodidae (Teleostei: Siluriformes). Int. J. Morphol., 25(4):735-748, 2007.

\section{DISCUSSION}

Five synapomorphies are commonly listed in catfi literature to support the monophyly of the subfamily Heptapterinae, namely: 1) "posterior limb of fourth transverse process laterally expanded above swimbladder and notched once to several times"; 2) "neural spines of Weberian complex centrum joined by a straight-edged, horizontal or sometimes sloping bony lamina"; 3) "process for insertion of levator operculi muscle on posterodorsal corner of hyomandibula greatly expanded"; 4) "quadrate with a free dorsal margin and bifid shape, its posterior and anterior limbs articulate separately with hyomandibula and metapterygoid"; 5) "presence of an anteriorly recurved process drawn out from ventrolateral corner of mesethmoid" (Lundberg et al., 1991: 198-199). Our own phylogenetic analysis, which included 440 characters and 87 terminal taxa representing all the extant catfish families (see Diogo, 2004), confirmed these five synapomorphies.

Additionally, our results also supported a synapomorphy that, although not usually referred most published studies on catfishes, does indeed seem to constitute a potential heptapterin synapomorphy: the well-developed maxilla forming a completely closed, deep tube to enclose the base of the maxillary barbel. This character was once described in an unpublished thesis by De Pinna (De Pinna, 1993), but, unfortunately, no reference to it was made since that unpublished work, including in De Pinna's recent survey of the synapomorphies and phylogenetic relationships of the subfamily Heptapterinae (De Pinna, 1998: 315-316). However, our study did point out that this feature probably constitutes a potential Heptapterinae synapomorphy. In fact, in non-heptapterin catfishes the maxilla is either only slightly concave at the surface where the base of the maxillary barbel is supported or eventually forms a semicircle of bone around this barbel but being tube-like only at a small site at its very base. But in heptapterins the whole main body of the maxillary bone assumes a cone-like tubular morphology (see Fig. 1), thus completely enclosing a significant part of the proximal tip of the maxillary barbel. As this character clearly constitutes a derived feature, and as it is found in all the heptapterins examined, which include the two main heptapterin groups and particularly the plesiomorphic genera Goeldiella and Rhamdia (see Lundberg et al., 1991), and in no other catfish studied by us or described in the literature, it does, thus, effectively seem to constitute a Heptapterinae synapomorphy.

But probably the more important aspect of our results is that they support the monophyly of the family Pimelodidae as a whole, that is, of the clade including the subfamilies subfamilies Heptapterinae, Pimelodinae and Pseudopimelodinae, thus contradicting the nowadays commonly accepted view that the Pimelodidae is a polyphyletic, shnnatural assemblage (see Introduction). Our phylogenetic analysis pointed out five characters that constitute, very likely, synapomorphies of a clade formed by the pimelodins, the heptapterins and the pseudopimelodins, two of which are uniquely present in these three groups among catfishes, and that, thus, strongly support the monophyly of the family Pimelodidae. These five characters are described below.

Presence of a 'muscle 4 of the mandibular barbels'. Plesiomorphically catfishes lack a 'muscle 4 of the mandibular barbels' (Diogo \& Chardon, 2000b; Diogo \& Vandewalle, 2003). However, in all the pimelodids examined, and in no other catfishes studied by us or described in the literature, there is a 'muscle 4 of the mandibular barbels', which is a well-developed structure connecting the proximal surface of the external mandibular barbels to both the antero-ventro-lateral surface of the cartilaginous plates carrying the mandibular barbels and the antero-mesial surfaces of the dentaries (see Fig. 4).

Presence of 'cartilaginous plates carrying the mandibular barbels'. As the presence of a 'muscle 4 of the mandibular barbels', the presence of 'cartilaginous plates carrying the mandibular barbels' (see e.g. Ghiot; Diogo \& Chardon, 2000b) is a derived feature present in all the pimelodins, pseudopimelodins and heptapterins examined (see Figs. 3 and 4), and in no other catfishes studied by us or described in the literature.

Origin of the muscle levator operculi on both the hyomandibulo-metapterygoid and the pterotic. Plesiomorphically in catfishes the muscle levator operculi originates exclusively on the neurocranium, namely on the pterotic (Diogo \& Vandewalle). However, in all the pimelodins, heptapterins and pseudopimelodins examined, a great part of the fibers of this muscle also originate on the postero-dorso-lateral surface of the hyomandibulometapterygoid (see Fig. 1). The origin of the levator operculi on both the neurocranium and the hyomandibulometapterygoid is a very rare feature among catfishes, being only present, apart the pimelodids, on a few catfishes such as plotosids, cranoglanidids, schilbids and silurids (Diogo $\&$ Vandewalle). As these latter four groups are very likely more closely related to other catfish groups than to the pimelodids (Mo; De Pinna, 1998; Diogo et al., 2002a; Diogo, 2004), this character supports the monophyly of the Pimelodidae.

Presence of an antero-dorsal projection of laminar bone on the anterior surface of the cleithrum. 
DIOGO, R. Osteology and myology of the cephalic region and pectoral girdle of Heptapterus mustelinus, comparison with other heptapterins, and discussion on the synapomorphies and phylogenetic relationships of the Heptapterinae and the Pimelodidae (Teleostei: Siluriformes). Int. J. Morphol., 25(4):735-748, 2007.

Plesiomorphically catfish lack major processes or projections on the anterior surface of the cleithrum (Diogo et al., 2001b). However, in all the pimelodids examined excepting Hypophthalmus edentatus, the cleithrum presents a well-developed, antero-dorsal projection of laminar bone (see Fig. 2: o-cl-adp). Since such a feature is present in all the pimelodids studied excepting the peculiar and highly derived pimelodin genus Hypophthalmus, and a somewhat similar feature is only present, among non-pimelodid catfishes, in some members of the phylogenetically distant Doradoidea (i.e., in some mochokids, auchenipterids and doradids examined) (e.g. Mo1; De Pinna, 1998; Diogo, 2004), this character also supports the monophyly of the Pimelodidae.

Anterior portion of ethmoid cartilage markedly extended anteriorly. One other derived character that seems to constitute a Pimelodidae synapomorphy and that, thus, supports the monophyly of this family, is the markedly anterior extension of the anterior portion of the ethmoid cartilage, which almost reaches the posterior surface of the premaxillaries. Contrarily to the vast majority of the Siluriformes, where the anterior portion of the ethmoid cartilage does not extends far beyond the anterior margin of the lateral ethmoids (see e.g. Mo; Diogo \& Chardon, 2000c), in all the pimelodins, pseudopimelodins and heptapterins examined this cartilage is markedly extended anteriorly, almost reaching the posterior margin of the premaxillaries. Such a feature is extremely rare among catfishes, only being found so far, apart the pimelodins, in the austroglanidids, claroteins and schilbids (see e.g. Diogo \& Chardon 2000c: Figs. 5 and 6). As these three groups seem to be more closely related to certain other catfish groups than to the pimelodids (Mo; De Pinna, 1998; Diogo et al., 2002a; Diogo, 2004), this character constitutes on more strong argument on behalf of the monophyly of the family Pimelodidae.

The five characters discussed above thus strongly support the monophyly of the clade formed by the subfamilies Heptapterinae, Pimelodinae, and Pseudopimelodinae, that is, of the family Pimelodidae as a whole. In particular, the first two characters, which concern the presence, exclusively in the pimelodids, of noticeable, distinct, easily recognized features, clearly constitute very strong evidence to support the monophyly of this family. In fact, as noted De Pinna (1998), the uniform, exclusive presence of a well-defined, distinct feature in a certain catfish group is extremely rare in a taxon as large and diverse as the Siluriformes. Thus, the presence of not only one, but of two of such features in the pimelodins is clearly a very strong argument on behalf of the monophyly of the Pimelodidae. And the taxonomic distribution of the three other characters, which refer, in any case, to rare features among catfishes (among 35 catfish families they are only present, besides pimelodins, in three or four other specific groups), and particularly the fact that the non-pimelodins where they are found are seemingly more closely related to certain other catfishes than to pimelodins, cannot also be helped to be considered as serious arguments in support of the monophyly of the Pimelodidae.

As referred above, this hypothesis contradicts the somewhat commonly accepted view nowadays that the Pimelodidae constitute a polyphyletic assemblage. However, it should not be forgotten than the only published work where this view was actually, explicitly stated, i.e., where was provided a phylogenetic hypothesis proposing that the three pimelodid subfamilies are in fact more closely related to other catfish groups than to each other, was that of De Pinna (1998). And, as, unfortunately, De Pinna's (1998) work does not provide the characters that support that phylogenetic hypothesis (De Pinna, 1998, refers to an unpublished PhD thesis by the same author), there are, in reality, no published characters to support such a view and, thus, to confront with the arguments given in the present study.

The strong evidence given in the present study to support the monophyly of the family Pimelodidae clearly seems related to the analysis of characters that are not, unfortunately, usually included in works concerning the phylogenetic relationships among catfishes, such as the structures associated with the mandibular barbels, the pectoral girdle structures or the cranial musculature. As other papers recently published by the author and colleagues (e.g. Diogo \& Chardon, 2000b, Diogo et al., 1999, 2000ab, 2001bc, 2002ab; Oliveira et al., 2002; Diogo, 2003a, 2004; Diogo \& Vandewalle, 2003), the present study thus stresses that the analysis of such features, and, particularly of the configuration of the cranial and pectoral girdle musculature, could reveal useful data for disclosing not only the phylogenetic relationships between different catfish groups, but also the respective synapomorphies and/or autapomorphies of these groups.

\section{ACKNOWLEDGEMENTS}

I thank J. Cambray (Albany Museum of Grahamstown), G.G. Teugels (Musée Royal de l'Afrique Centrale), P. Laleyé (Université Nationale du Bénin), R. Vari, J. Williams and S. Jewett (National Museum of Natural History) and P. Duhamel (Muséum National D'Histoire Naturelle) for kindly providing a large part of the catfishes studied. I would also like to acknowledge I. Doadrio, I. Peng, G.G. Teugels, R.P. Vari, S. Weitzman, T. Abreu, A. Zanata, B.G. Kapoor, F. Meunier, S. He, D. Adriaens, F. Wagemans, 
DIOGO, R. Osteology and myology of the cephalic region and pectoral girdle of Heptapterus mustelinus, comparison with other heptapterins, and discussion on the synapomorphies and phylogenetic relationships of the Heptapterinae and the Pimelodidae (Teleostei: Siluriformes). Int. J. Morphol., 25(4):735-748, 2007.

C. Oliveira, E. Parmentier, M.M. de Pinna, P. Skelton, M.J.L. Stiassny, F.J. Poyato-Ariza, G. Arratia, T. Grande, M.G., H. Gebhardt, M. Ebach, A. Wyss, J. Waters, B. Perez-Moreno, G. Cuny, A. Choudhury, M. Vences, S.H. Weitzman, L.
Cavin, F. Santini, J.C. Briggs, L.M. Gahagan, Philiphe J.G. Maisey, M. Gayet, J. Alves-Gomes, G. Lecointre, C. Borden, and specially M. Chardon, P. Vandewalle and L. Taverne for their helpful discussions, criticism, advice and assistance.

DIOGO, R. Osteología y miología de la región cefálica y de la cintura pectoral del Heptapterus mustelinus, comparación con otros heptapterinos, y discusión de las sinapomorfías y relaciones filogenéticas de los Heptapterinae y Pimelodidae (Teleostei: Siluriformes). Int. J. Morphol., 25(4):735-748, 2007.

RESUMEN: Las estructuras de la región cefálica y de la cintura pectoral de Heptapterus mustelinus ('Nemuroglanis clade') son descritas y comparadas con las de dos representantes de un grupo más plesiomórfico, Goeldiella eques y Rhamdia guatemalensis ('basal clade'), así como las de otros peces gato, como fundamento para la discusión de las relaciones filogenéticas y de las sinapomorfías de los Heptapterinae. Además, de las cinco sinapomorfías referidas comúnmente en la literatura, este estudio advierte una otra sinapomorfía de Heptapterinae: la bien desarrollada maxila formando un tubo completamente cerrado para la base del bigote maxilar. Las subfamilias Pimelodinae, Heptapterinae y Pseudopimelodinae parecen formar un grupo natural.

PALABRAS CLAVE: Pez gato; Heptapterinae; Morfología; Filogenia; Pimelodidae; Siluriformes.

\section{REFERENCES}

Alexander, R. M. Structure and function in catfish.J.Zool.(Lond.), 148:88-152, 1965.

Arratia, G. Development and variation of the suspensorium of primitive catfishes (Teleostei: Ostariophysi) and their phylogenetic relationships. Bonn.zool.Monogr., 32:1-148, 1992.

Bockmann, F. A. Description of Mastiglanis asopos, a new pimelodid catfish from Northern Brazil, with comments on phylogenetic relationships inside the subfamily Rhamdiinae (Siluriformes: Pimelodidae). Proc. Biol. Soc. Wash., 107:76077, 1994.

Buckup, P. A. The genus Heptapterus (Teleostei, Pimelodidae) in Southern Brazil and Uruguay, with description of a new species. Copeia, 641-53, 1988.

Chardon, M. Anatomie comparée de l'appareil de Weber et des structures connexes chez les Siluriformes. Ann. Mus. R. Afr. Centr., 169:1-273, 1968.

De Pinna, M. C. C. Higher-level phylogeny of Siluriformes, with a new classification of the order (Teleostei, Ostariophysi). Unpublished PhD thesis, City University of New York, 1993.

De Pinna, M. C. C. Phylogenetic relationships of Neotropical Siluriformes: History overview and synthesis of hypotheses. In Malabarba, L. R.; Reis, R. E.; Vari, R. P.; Lucena, Z. M. Lucena, C. A. S. eds. Phylogeny and Classification of Neotropical Fishes. Porto Alegre, Edipucrs, pp. 279-330, 1998.

Diogo, R. Higher-level phylogeny of Siluriformes: an overview. In Arratia, G.; Kappor, B. G.; Chardon, M. \& Diogo, R. eds. Catfishes. Enfield, Science Publishers, pp. 353-84, 2003.
Diogo, R. Morphological evolution, aptations, homoplasies, constraints, and evolutionary trends: catfishes as a case study on general phylogeny and macroevolution. Enfield, Science Publishers, 2004.

Diogo, R. \& Chardon, M. Anatomie et fonction des structures céphaliques associées á la prise de nourriture chez le genre Chrysichthys (Teleostei: Siluriformes). Belg. J.Zool., 130:2137, 2000a.

Diogo, R. \& Chardon, M. Homologies between different adductor mandibulae sections of teleostean fishes, with a special regard to catfishes (Teleostei: Siluriformes). J. Morphol., 243:193-208, 2000b.

Diogo, R. \& Chardon, M. The structures associated with catfish (Teleostei: Siluriformes) mandibular barbels: Origin, Anatomy, Function, Taxonomicdistribution, Nomenclature and Synonymy. Neth. J.Zool., 50:455-78, 2000c.

Diogo, R. \& Chardon, M. Homologies and evolutionary transformation of the skeletal elements of catfish (Teleostei: Siluriformes) suspensorium: a morphofunctional hypothesis In AL Val, BG Kapoor, eds. Fish adaptations. Enfield, Science Publishers, pp. 275-84, 2003.

Diogo, R. \& Vandewalle, P. Review of superficial cranial musculature of catfishes, with comments on plesiomorphic states. In Arratia, G.; Kappor, B. G.; Chardon, M. \& Diogo, R. eds. Catfishes. Enfield, Science Publishers, pp. 47-69, 2003.

Diogo, R.; Vandewalle, P. \& Chardon, M. Morphological description of the cephalic region of Bagrus docmak, with a reflection on Bagridae (Teleostei: Siluriformes) autapomorphies. Neth. J. Zool., 49:207-32, 1999. 
DIOGO, R. Osteology and myology of the cephalic region and pectoral girdle of Heptapterus mustelinus, comparison with other heptapterins, and discussion on the synapomorphies and phylogenetic relationships of the Heptapterinae and the Pimelodidae (Teleostei: Siluriformes). Int. J. Morphol., 25(4):735-748, 2007.

Diogo, R; Oliveira, C. \& Chardon, M. The origin and transformation of catfish palatine-maxillary system: an example of adaptive macroevolution. Neth. J. Zool., 50:373-88, 2000a.

Diogo, R; Oliveira, C. \& Chardon, M. On the anatomy and function of the cephalic structures in Phractura (Siluriformes: Amphiliidae), with comments on some striking homoplasies occurring between the doumeins and some loricarioids catfishes. Belg. J. Zool., 130:117-30, 2000b.

Diogo, R; Oliveira, C. \& Chardon, M. On the homologies of the skeletal components of catfish (Teleostei: Siluriformes) suspensorium. Belg. J. Zool., 131:155-71, 2001a.

Diogo, R; Oliveira, C. \& Chardon, M. On the osteology and myology of catfish pectoral girdle, with a reflection on catfish (Teleostei: Siluriformes) plesiomorphies. J.Morphol., 249:100$25,2001 b$

Diogo, R; Oliveira, C. \& Chardon, M. Osteology and myology of the cephalic region and pectoral girdle of the Chinese catfish Cranoglanis bouderius, with a discussion on the autapomorphies and phylogenetic relationships of the Cranoglanididae (Teleostei: Siluriformes). J. Morphol., 253:229-42, 2002a.

Diogo, R; Oliveira, C. \& Chardon, M. Osteology and myology of the cephalic region and pectoral girdle of Glyptothorax fukiensis (Rendahl, 1925), comparison with other sisorids, and comments on the synapomorphies of the Sisoridae (Teleostei: Siluriformes). Belg. J. Zool., 132:93-101, 2002b.

Ferraris, C. J. Relationships of the Neotropical catfish genus Nemuroglanis, with a description of a new species (Osteichthyes: Siluriformes: Pimelodidae). Proc. Biol. Soc. Wash., 101:509-16, 1988.

Ferraris, C. J. \& De Pinna, M.C.C. Higher-level names for Catfishes (Actinopterygii: Ostariophysi: Siluriformes).Proc. Calif.Acad. Sci., 51:1-17, 1999 .

Ghiot, F. The barbel movements of three South American Pimelodid Catfishes. Zool. Anz., 200:1-7, 1978.

Gosline, W.A. The palatine-maxillary mechanism in catfishes with comments on the evolution and zoogeography of modern siluroids. Occ. Pap. Calif. Acad. Sci., 120:1-31, 1975.

Gosline, W.A. Two patterns of differentiation in the jaw musculature of teleostean fishes. J. Zool. (Lond.), 218:649-61, 1989.

Howes, G. J. The cranial muscles of the loricarioid catfishes, their homologies and value as taxonomic characters. Bull. Br. Mus. Nat. Hist. (Zool.), 45:309-45, 1983.

Howes, G.J. The phylogenetic relationships of the electric family Malapteruridae (Teleostei: Siluroidei). J. Nat. Hist., 19:37-67, 1985.
Lundberg, G. L. \& McDade, L. A. On the South American catfish Brachyrhamdia imitator Myers (Siluriformes, Pimelodidae), with phylogenetic evidence for a large intrafamilial lineage. Not. Nat. Acad. Nat. Sci. Phil., 463:1-24, 1986.

Lundberg, G. L.; Bornbusch, A. H. \& Mago-Leccia, F. Gladioglanis conquistador $\mathrm{n}$. sp. from Equador with diagnoses of the subfamilies Rhamdiinae Blekker and Pseudopimelodinae $\mathrm{n}$. subf. (Siluriformes: Pimelodidae). Copeia, 190-209, 1991.

McMurrich, J. P. On the osteology of Amiurus catus (L) Gill. Zool. Anz., 168:296-99, 1884.

Mo, T. Anatomy, relationships and systematics of the Bagridae (Teleostei: Siluroidei) with a hypothesis of siluroid phylogeny. Theses Zoologicae, 17:1-216, 1991

Oliveira, C.; Diogo, R.; Vandewalle, P. \& Chardon, M. Osteology and myology of the cephalic region and pectoral girdle of Plotosus lineatus, with comments on Plotosidae (Teleostei: Siluriformes) autapomorphies.J.Fish.Biol., 59:243-66, 2001.

Oliveira, C.; Diogo, R.; Vandewalle, P. \& Chardon, M. On the myology of the cephalic region and pectoral girdle of three ariid species, Arius heudeloti, Genidens genidens and Bagre marinus, and comparison with other catfishes (Teleostei: Siluriformes). Belg. J. Zool., 132:17-24, 2002.

Shibatta, O. A. Phylogeny and classification of 'Pimelodidae'. In Kapoor, B. G.; Arratia, G.; Chardon, M. \& Diogo, R. eds. Catfishes. Enfield, Science Publishers, pp. 385-400, 2003.

Silfvergrip,A. M. C. A systematic revision of the Neotropical catfish genus Rhamdia (Teleostei, Pimelodidae). Stockholm, Swedish Museum of Natural History, 1996.

Taylor, W. R. \& Van Dyke, G. C. Revised procedures for staining and clearing small fishes and other vertebrates for bone and cartilage study. Cybium, 9:107-19, 1985.

Teugels, G. G. State of the art of recent siluriform systematics. In Arratia, G.; Kappor, B. G.; Chardon, M. \& Diogo, R. eds. Catfishes. Enfield, Science Publishers, pp. 317-52, 2003.

Winterbottom, R. A descriptive synonymy of the striated muscles of the Teleostei. Proc. Acad. Nat. Sci. (Phil.), 125:225-317, 1974.

\section{Correspondence to:}

Dr. Rui Diogo,

Department of Anthropology

The George Washington University

2110 G St. NW

Washington, DC 20052

USA

Email: R.Diogo@ulg.ac.be

Received: 06-04-2006

Accepted: 10-08-2007 